\title{
Anti-oxidant, anti-inflammatory, and anti-bacterial effects of extracts from Elaeagnus umbellata leaves obtained using different extract conditions
}

\author{
Ha-Rin Kang ${ }^{1}$, Jong-Kang Jung ${ }^{2}$, Se-Ho Park ${ }^{3,4}$, Jae-Yeul Lee ${ }^{3,4}$, Seun-Ah Yang ${ }^{2 *}$ \\ ${ }^{1}$ Department of Biological Sciences, Keimyung University, Daegu 42601, Korea \\ ${ }^{2}$ Department of Food Science and Technology, Keimyung University, Daegu 42601, Korea \\ ${ }^{3}$ Department of Applied Chemisty, Kumoh National Institute of Technology, Gumi 39177, Korea \\ ${ }^{4}$ Institute of Natural Science, Keimyung University, Daegu 42601, Korea
}

\section{추출 조건에 따른 보리수나무 잎 추출물의 항산화, 항염증 및 항균 효과

\author{
강하린 ${ }^{1}$ - 정종강 ${ }^{2}$ - 박세호 ${ }^{3,4}$ - 이재열 ${ }^{3,4}$. 양선아 ${ }^{2 *}$ \\ ${ }^{1}$ 계명대학교 생명과학전공, ${ }^{2}$ 계명대학교 식품가공학과,
} \\ ${ }^{3}$ 금오공과대학교 응용화학과, ${ }^{4}$ 계명대학교 자연과학연구소}

\begin{abstract}
To investigate the optimum extraction condition for Elaeagnus umbellata, the antioxidant, anti-inflammatory and antibacterial effects of the extracts were assessed under different extraction conditions. Gallic acid and kaempferol, known as major components, were quantitatively by HPLC. Extracts of $E$. umbellata were examined in terms of their DPPH and ABTS radical scavenging abilities in addition to their polyphenol and flavonoid contents to determine their antioxidant activities. In addition, their inhibition of nitric oxide (NO) production in LPS-stimulated RAW264.7 cells was examined to determine their anti-inflammatory effects, and paper diffusion assays were used to examine their anti-microbial activities against Propionibacterium acnes, Staphylococcus aureus, and Escherichia coli. It was found that the extract obtained using $70 \% \mathrm{EtOH}$ at $80^{\circ} \mathrm{C}$ for $6 \mathrm{~h}$ showed the best radical scavenging activities $\left(\mathrm{IC}_{50} ; 8.64 \pm 0.31 \mu \mathrm{g} / \mathrm{mL}\right.$ against DPPH, $9.44 \pm 0.48 \mu \mathrm{g} / \mathrm{mL}$ against ABTS) and NO inhibition in RAW264.7 cells $(39.6 \%$ at $500 \mu \mathrm{g} / \mathrm{mL})$. In addition, the extract obtained using 50-70\% EtOH at $20-80^{\circ} \mathrm{C}$ for $6 \mathrm{~h}$ exhibited an excellent antimicrobial activity $(\mathbf{7 . 0} \pm 0.4,6.5 \pm 0.5$, and $9.0 \pm 1.0 \mathrm{~mm}$ against $P$. acnes, $S$. aureus, and $E$. coli, respectively). This extract also contained the highest contents of gallic acid $(45.60 \mu \mathrm{g} / \mathrm{mg})$ and $\mathrm{kaempferol}(1.16$ $\mu \mathrm{g} / \mathrm{mg}$ ), and the highest extraction yield (16.83\%). Our data therefore confirm that the gallic acid-rich $E$. umbellata extract exhibits enhanced antioxidant, anti-inflammatory, and antimicrobial effects, and can be used as a functional food to protect against skin aging and/or dermatological issues, such as acne and atopy.
\end{abstract}

Key words : anti-bacterial activity, anti-inflammatory effect, anti-oxidant activity, Elaeagnus umbellata, gallic acid

서 론

보리수나무(Elaeagnus umbellata Thunb.)는 보리수나무 과(Elaeagnaceae)에 속하는 낙엽활엽 관목으로서 국내에
서 보리똥나무, 벌똥, 핑크팝 보리수로도 알려져 있다. 국 내에서는 경남 합천군 지역에서 유기농, 친환경으로 재배 되며, 열매와 잎은 식용 가능한 소재이다. 열매는 한방에 서는 목반하(木米夏)라 하며, 설사(Rafique 등, 2016), 출혈

*Corresponding author. E-mail : seunahy@kmu.ac.kr, Phone : +82-53-580-5117, Fax : +82-53-580-5372

Received 17 January 2020; Revised 21 February 2020; Accepted 24 February 2020.

Copyright (c) The Korean Society of Food Preservation.

This is an Open Access article distributed under the terms of the Creative Commons Attribution Non-Commercial License (http://creativecommons.org/licenses/by-nc/4.0) which permits unrestricted non-commercial use, distribution, and reproduction in any medium, provided the original work is properly cited. 
(Lee 등, 2011), 소화불량(Lee 등, 2011) 등에 효과가 있고, 라이코펜이 토마토의 7-8배 정도 함유되어 있는 것으로 알려져 있고, 보리수나무 잎의 생리 활성에 대한 보고로는 천식 예방 효과 및 미백, 주름개선 효과(Park 등, 2019) 및 항암 활성 $(\operatorname{Kim}$ 등, 2016) 등의 다양한 효능이 보고되었 다. 하지만 보리수나무 잎의 여드름균의 피부 질환에 대한 효능 검증은 보고된 바 없다.

보리수나무 잎의 주요 활성 성분에 대한 연구는 미흡한 실정이나, gallic acid, kaempferol, catechin 등이 주요 성분 으로 함유되어있는 것으로 알려져 있다(Yoon 등, 2007; Abri와 Maleki, 2016; Kim 등, 2016). Gallic acid는 항산화 소재로 활용되고 있으며(Yen과 Duh, 2002), 항염 활성 (Kroes 등, 1992), 백혈구의 자연 사멸 유도(Inoue 등, 1994), 항알러지 효과(Kim 등, 2006b), 폐암 증식 억제(Ohno 등, 1999), 구강 내 박테리아의 생육 억제(Kang 등, 2008) 등이 보고되어 있다. 특히, gallic acid의 함량이 높은 녹차의 뛰어난 항산화 효능은 잘 알려져 있다. Kaempferol도 gallic acid와 동일하게 식물 내 다량 존재하는 phenolic component 중 하나이며, 항염 활성(Devi 등, 2015)이 우수하며, 신경 교 세포의 산화적 스트레스 완화 효과(Sharma 등, 2007) 등의 연구가 있다.

피부는 인체의 겉 부분을 덮는 조직으로 자외선이나 공해와 같은 외부자극이나 화학 물질로부터 보호기능을 가지며, 병원성 미생물에 대한 방어체계를 갖는다(Kim 등, 2010). 하지만, 외부 자극에 지속적으로 노출이 되어 손상 을 받기 쉽다. 여드름은 우리나라 피부 질환 환자의 6- $8 \%$ 를 차지하는 흔한 피부 질환으로, 성인 여드름은 과도한 스트레스 또는 생활 패턴에 따른 피부 장벽 손상으로 인하 여 발생되며, 모공 내 피지의 분비 증가, Propionibacterium acnes 등의 과도한 증식, 피부 장벽에서의 염증 반응 등이 복합적으로 작용하여 발생한다(Sohn 등, 2006; Kim 등 2006a; Kim 등, 2009). 그리고 병원 치료와 더불어 효과적 이면서 자극이 적은 화장품의 중요성이 부각되면서 천연 화장품에 대한 관심이 급증하고 있다.

피부질환을 유발시키는 미생물은 Staphylococcus aureus, P. acnes가 보고되어 있다. S. aureus는 피부 상재균으로 아토피 피부염 환자의 피부에서 $95 \%$ 이상의 S. aureus의 군집에 의해 아토피가 유발된다는 보고 사례들이 있으며, P. acnes는 주로 여드름을 유발하는 박테리아로 알려져 있으며, 모낭과 피지선에 분포하여 모낭 내부에서 P. acnes 의 지방 분해 효소가 피지를 분해하고, 유리 지방산을 생 성하여 모공 주위의 세포에 염증을 일으킨다. 이와 같이 피부 상재균의 이상 증식은 피부 질환을 유발시킬 뿐만 아니라, 모공 주위의 세포나 장벽 기능에 손상을 야기할 수 있다(Han 등, 2009; Weon 등, 2011).

현재 보고된 여드름 치료제 성분으로 triclosan(Lee 등,
1998), benzoyl peroxide(Leem과 Jung, 2005), azelaic acid (Bojar 등, 1991), retinoid(Pechere 등, 2002), tetracycline (Leyden 등, 1996), erythromycin(Lim 등, 2007), roxithromycin (Kobayashi 등, 2009), clindamycin(Lim 등, 2007)이 있지만, 여드름 치료제의 과도한 사용에 의한 내성 문제가 제기되 고 있다. 따라서 부작용이 나타나지 않고 피부의 과도한 염증 발생에 대한 개선 효과를 갖는 소재 개발이 절실한 실정이다. 여드름 원인균에 대한 항균 또는 항염 효과를 나타내는 천연 추출물은 연잎(Nelumbo nucifera)(Lee 등, 2019), 병풀(Centella asiatica L. Urban)(George와 Joseph, 2009; Shen 등, 2018), 보골지(Psoralea corylifolia L.)(Chen 등, 2017), 당후박(Magnoliae officinalis)(Park 등, 2004; Oh 등, 2009), 목향(Inula helenium L.)(Wang 등, 2018), 구절초 (Chrysanthemum zawadskii var. latilobum)(Kim 등 2012b; $\mathrm{Ku}$ 와 Park, 2018) 등이 있다.

활성 산소종(reactive oxygen species, ROS)에 의해 신체 내 대사 작용 및 세포소기관의 파괴, 유전자 변형 등 다양 한 신체 저해 요인이 나타난다. 신체 내 ROS를 제거하기 위해 vitamin $\mathrm{C}$ 와 같은 물질을 흡수함으로써 신체를 보호 한다(Wang 등, 2000).

본 연구에서는 보리수나무 잎의 주요 성분 함량, 피부 염증 예방 효능의 극대화를 위해 추출 용매의 농도, 추출 온도, 추출 시간의 추출 조건에 따른 추출물의 활성을 비 교 분석하였다. 보리수나무 잎 추출물의 gallic acid와 kaempferol 함량은 HPLC를 사용하여 분석하였고, 보리수 나무 잎의 피부 염증 개선 효능을 검증하기 위해 항산화, 항염증 활성 및 피부 염증을 유발하는 포도상구균 $(S$. aureus), 여드름 균(P. acnes)에 대한 항균 효과 및 그람 양성 균에 대한 유효성을 검증하기 위해 대장균(Escherichia coli) 을 사용하여 항균활성을 확인하였다.

\section{재료 및 방법}

\section{실험재료}

본 실험에 사용된 보리수나무 잎은 보사모영농조합법 인(Gyeongnam, Korea)으로부터 제공 받아 사용하였다. Ascorbic acid, prethanol A, sodium carbonate, sodium chloride는 Duksan Chemical(Seoul, Korea)에서 구매하였 고, agar는 OCI Chemical(Seoul, Korea), dextrose는 Samchun Chemical(Seoul, Korea), 2,2'-azino-bis(3-rthyl-benzthiazoline6-sulfonic acid)-diammonium salt(ABTS), chloramphenicol, 2,2-diphenyl-1-picrylhydrazyl(DPPH), aluminum nitrate, beef extract, Folin-Ciocalteu reagent, gallic acid, L-cysteine hydrochloride, peptone, potassium acetate, phosphate buffer saline, potassium persulfate, soluble starch, sodium acetate, kaempferol, quercetin, yeast extract는 Sigma-Aldrich-Chemical 
Co.(St. Louis, MO, USA)에서 구매하였다. 대장균(E. coli), 포도상구균(S. aureus), 여드름 균(P. acnes)는 생물자원 센 터(KCTC, Seoul, Korea)로부터 분양받아 사용하였다.

\section{보리수나무 잎 추출물 제조 및 수율 측정}

본 실험에 사용된 보리수나무 잎은 보사모영농조합법 인(Hapcheon, Korea)으로부터 제공받아 사용하였다. 건조 된 보리수나무 잎의 추출 조건은 에탄올의 비율 $(0,20,50$, $70 \%$ ethanol), 추출 온도 $\left(20,60,80^{\circ} \mathrm{C}\right)$, 추출 시간 $(3,6,12$, $24,48 \mathrm{~h}$ )을 변수로 하였으며, 건조된 보리수나무 잎을 추 출 용매와 혼합 및 교반시켜 추출하였다. 보리수나무 잎 추출액을 여과지(Advantec, No. 5A, Tokyo, Japan)로 여과한 후 동결건조기(FDU-2100, EYELA, Japan)로 동결건조하여 분말 형태로 회수하였다. 회수한 추출물은 $-20^{\circ} \mathrm{C}$ 에서 보 관하여 사용하였다. 보리수나무 잎 추출물의 수율은 추출 전 보리수나무 잎 초기 무게에 대한 동결 건조 후 추출물 의 무게 변화를 측정하여 백분율로 계산하였다.

\section{보리수나무 잎 추출물의 HPLC 분석}

보리수나무 잎 추출물의 gallic acid(Fernandes 등, 2015) 와 kaempferol(Wang 등, 2003)의 함량 분석은 HPLC (Shimazu, Kyoto, Japan)를 이용하였으며, UV detector (HPLC-20A, Shimazu)를 사용하여 gallic acid는 $270 \mathrm{~nm}$ 의 파장에서 kaempferol은 $370 \mathrm{~nm}$ 의 파장에서 분석하였다. Gallic acid와 kaempferol의 함량 분석에는 동일하게 $\mathrm{C}_{18}$ column(ProntoSil 120-5-C18 ACE-EPS, 250×4.6 mm, $5 \mu \mathrm{m}$, Bischoff chromatography, Stuttgart, Germany)를 사용하였으 며, $1 \mathrm{~mL} / \mathrm{min}$ 의 flow rate, $30^{\circ} \mathrm{C}$ 의 oven의 온도를 유지하고, 증류수(with $0.05 \%$ phosphoric acid, solvent A)와 메탄올 (with $0.05 \%$ phosphoric acid, solvent B)을 초기 시간의 solvent $\mathrm{A}$ 와 $\mathrm{B}$ 의 비율을 $80: 20$ 의 기울기 용리로 하여 10 분 에 solvent $\mathrm{B}$ 의 비율이 $100 \%$ 가 되도록 조절하였다. 보리수 나무 잎 추출물은 성분 함량의 비교를 위해 $1 \mathrm{mg} / \mathrm{mL}$ 의 동일한 농도를 사용하였으며, $10 \mu \mathrm{L}$ 의 부피로 injection 하였다. 보리수나무 잎 추출물의 gallic acid와 kaempferol 의 함량은 standard gallic acid와 kaempferol을 HPLC를 이 용하여 측정한 후 검량선을 작성하여 분석하였다.

\section{$\mathrm{DPPH}$ 라디칼 소거 활성 측정}

각 농도별 보리수나무 잎 추출물 $100 \mu \mathrm{L}$ (final concentration: $2.5,5,12.5,25 \mu \mathrm{g} / \mathrm{mL}$ )와 $0.2 \mathrm{mM} \mathrm{DPPH}$ 용액 100 $\mu \mathrm{L}$ 를 96-well plate에 넣고 혼합하여 30분 동안 상온, 암실 상태에서 반응시킨 후 microplate reader(CA 94089, Molecular Devices, USA)를 이용하여 $517 \mathrm{~nm}$ 에서의 흡광도를 측정 하였다. 동일한 조건에서 3회의 반복 실험 후 평균값을 계산하여 사용하였으며, 보리수나무 잎 추출물의 DPPH
라디칼 소거활성은 inhibition concentration $50 \%\left(\mathrm{IC}_{50}\right)$ 값으 로 나타내었다. 대조군으로 gallic acid의 $\mathrm{IC}_{50}$ 값을 계산하 여 보리수나무 잎 추출물과 비교하였다.

\section{$\mathrm{ABTS}$ 라디칼 소거활성 측정}

$14 \mathrm{mM}$ 2,2'-Azino-bis(3-ethylbenzothiazoline-6-sulfonic acid) diammonium salt와 $4.9 \mathrm{mM}$ potassium persulfate를 혼 합하여 상온과 암소 상태에서 24시간 동안 반응시켜 $\mathrm{ABTS}$ radical을 형성시킨 후 $734 \mathrm{~nm}$ 에서의 흡광도가 0.70 이 되도 록 희석하였다. 각 농도별 보리수나무 잎 추출물 $20 \mu \mathrm{L}$ (final concentration: $1,2.5,5,10,25 \mu \mathrm{g} / \mathrm{mL}$ )와 ABTS solution $180 \mu \mathrm{L}$ 를 96-well plate에 넣어 혼합시켰다. 그 후, 상온에서 30 분 동안 암소 반응시켜 microplate reader를 이 용하여 $734 \mathrm{~nm}$ 에서의 흡광도를 측정하였다. 보리수나무 잎 추출물의 라디칼 소거활성을 $\mathrm{IC}_{50}$ 값으로 나타냈다. 대 조군으로 quercetin의 $\mathrm{IC}_{50}$ 값을 계산하여 보리수나무 잎 추출물과 비교하였다.

\section{총 폴리페놀 함량 측정}

보리수나무 잎 추출물의 총 폴리페놀 함량은 FolinDenis법을 이용하였다. 각 농도별 보리수나무 잎 추출물 (final concentration: 100, 1,000 $\mu \mathrm{g} / \mathrm{mL}$ ) $60 \mu \mathrm{L}$ 를 96-well plate에 분주하고, $1 \mathrm{~N}$ Folin-Denis reagent $60 \mu \mathrm{L}$ 를 혼합하 여 3 분 동안 실온에서 반응시킨 후 $60 \mu \mathrm{L}$ 의 $10 \% \mathrm{Na}_{2} \mathrm{CO}_{3}$ 용액을 혼합하여 암실에서 30 분 반응시켰다. 반응 이후, microplate reader를 이용하여 $700 \mathrm{~nm}$ 에서의 흡광도를 측 정하였다. Gallic acid를 사용하여 표준 곡선을 작성하여 보리수나무 잎 추출물의 총 폴리페놀 함량을 구하였다.

\section{총 플라보노이드 함량 측정}

보리수나무 잎 추출물의 총 플라보노이드 함량은 Moreno 방법을 이용하여 측정하였다. 각 농도별 보리수나무 잎 추출물(final concentration: $500,1,000 \mu \mathrm{g} / \mathrm{mL}$ ) $100 \mu \mathrm{L}$ 와 $10 \%$ aluminum nitrate $20 \mu \mathrm{L}, 1 \mathrm{M}$ potassium acetate $20 \mu \mathrm{L}$, $100 \%$ ethanol $860 \mu \mathrm{L}$ 를 순서대로 혼합하여 실온에서 40 분 동안 반응시켰다. 96-Well plate에 $200 \mu \mathrm{L}$ 씩 분주하여 415 $\mathrm{nm}$ 에서의 흡광도를 측정하였다. Quercetin을 사용하여 표 준 곡선을 작성하여 보리수나무 잎 추출물의 총 플라보노 이드 함량을 구하였다.

\section{세포 배양}

본 연구에 사용된 대식세포주(RAW264.7, KCLB40071)는 한국세포주은행(KCLB, Seoul, Korea)에서 분양받았으며, $1 \%$ penicillin-streptomycin(Welgene, Daegu, Korea)과 $10 \%$ fetal bovine serum(FBS, Welgene)이 포함된 DMEM(Welgene) 를 사용하여 $37^{\circ} \mathrm{C}, 5 \% \mathrm{CO}_{2}$ 의 조건 하에 배양하였다. 


\section{보리수나무 잎 추출물에 대한 세포 생존율 측정}

세포 생존율 측정을 위하여 96-Well plate에 대식세포주 를 $1 \times 10^{5}$ cells/well로 seeding하고, 24 시간 동안 $5 \% \mathrm{CO}_{2}$ 조건에서 배양한 후, 다양한 보리수나무 잎 추출물의 농도 $(100,250,500 \mu \mathrm{g} / \mathrm{mL})$ 로 처리하여 24시간 배양하였다. 배 양 이후, 최종 농도가 $5 \mu \mathrm{g} / \mathrm{mL}$ 가 되도록 MTT 용액을 넣고 $37^{\circ} \mathrm{C}, 5 \% \mathrm{CO}_{2}$ 조건에서 4 시간 동안 반응시킨 후, microplate reader를 이용하여 $550 \mathrm{~nm}$ 에서의 흡광도를 측정하고, 대조 군에 대한 세포 생존율을 백분율로 표시하였다. $\mathrm{N \omega}$ -nitro-L-arginine methyl ester hydrochloride(L-NAME, $250 \mu$ $\mathrm{M})$ 는 positive control로 사용하였다.

\section{보리수나무 잎 추출물의 산화질소(NO) 생성 억제 측정}

산화질소 생성에 대한 보리수나무 잎 추출물의 효과를 알아보기 위하여 Griess reagent를 사용하여 NO의 생성량을

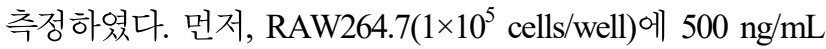
의 LPS를 보리수나무 잎 추출물 $(100,250,500 \mu \mathrm{g} / \mathrm{mL})$ 과 함께 처리하고 24 시간 동안 반응시켰다. 각 실험군의 배지 $100 \mu \mathrm{L}$ 와 griess reagent $[1 \%$ sulfanilamide, $0.1 \% \quad N-(1-$ naphtyl)-ethylene diamine dihydrochloride in $2.5 \%$ phosphoric acid]를 동량으로 혼합하고, $540 \mathrm{~nm}$ 파장에서의 흡광도를 측정하였다. 산화질소 생성량은 sodium nitrate $\left(\mathrm{NaNO}_{3}\right)$ 를 표 준으로 사용하여 검량선을 작성하여 계산하였다. Positive control로 iNOS의 활성을 저해함으로써 $\mathrm{NO}$ 의 생성을 억 제하는 inhibitor인 L-NAME $(250 \mu \mathrm{M})$ 을 사용하였다.

\section{균 배양}

E. coli, S. aureus는 $5 \mathrm{~mL}$ 의 $\mathrm{NB}$ 배지에 $50 \mu \mathrm{L}$ 를 접종하고, $37^{\circ} \mathrm{C}$ 에서 24시간 shaking incubator(HB-2012SF, Hanbaek Science, Bucheon, Korea)을 사용하여 배양하였다. P. acnes 는 $5 \mathrm{~mL}$ 의 $\mathrm{RCM}$ 배지에 $50 \mu \mathrm{L}$ 를 접종한 후 gas pack anaerobic system의 $37^{\circ} \mathrm{C}, 5 \% \mathrm{CO}_{2}$ 조건에서 48 시간 동안 정치 배양하였다.

\section{보리수나무 잎 추출물의 항균 활성 측정}

보리수나무 잎 추출물의 항균력 측정은 disc diffusion method를 이용하였다. E. coli, S. aureus, P. acnes를 사용하 였으며, E. coli와 S. aureus는 $1 \times 10^{6} \mathrm{CFU} / \mathrm{mL}$ 의 균의 수로 $\mathrm{NB}$ 배지에 도말 하였다. P. acnes는 $2 \times 10^{6} \mathrm{CFU} / \mathrm{mL}$ 의 균의 수로 RCM 고체배지에 도말 하였다. E. coli, S. aureus가 도말된 고체배지 위에 paper $\operatorname{disc}(6 \mathrm{~mm}$, ADVANTEC, Asan, Korea)를 위치시키고, 보리수나무 잎 추출물 $(100 \mu \mathrm{g})$ 을 주입하여 $37^{\circ} \mathrm{C}$ 에서 24 시간 동안 배양하였다. 24 시간 배양 후, 보리수나무 잎 추출물에 의해 생성된 clear zone을 측정하였다. 또한, P. acnes가 도말된 고체배지에 paper $\operatorname{disc}$ 를 위치시키고, 보리수나무 잎 추출물 $(1 \mathrm{mg})$ 을 주입하
여 $37^{\circ} \mathrm{C}, 5 \% \mathrm{CO}_{2}$ 조건에서 24 시간 동안 배양하였다. Positive control로 chloramphenicol $(0.1 \mathrm{mg} / \mathrm{mL})$ 을 사용하였다.

\section{통계분석}

본 실험에서 얻어진 결과에 모든 값은 3 회 이상의 반복 실험의 측정값의 평균표준오차로 나타내었으며, 실험 결 과 값에 대한 통계적 분석은 $\mathrm{SPSS}^{\circledR}$ version 11(SPSS Inc., Chicago, IL, USA)을 사용하여 각 시료별 측정 결과를 one-way ANOVA test를 실시하였으며, 사후분석은 Tukey 법으로 검정하였다. $\mathrm{p}$ 값이 0.05 이하이면 유의성이 있다고 판단하였다.

\section{결과 및 고찰}

\section{추출 조건에 따른 추출물의 수율, gallic acid 및 kaempferol 함량}

보리수나무 잎을 다양한 추출 조건에서 추출하였으며, 추출 수율은 Table 1에 나타내었다. 에탄올 농도에 따른 추출 조건 $\left(0-70 \% \mathrm{EtOH}, 20^{\circ} \mathrm{C}, 6 \mathrm{~h}\right)$ 에서 보리수나무 잎 추출물의 추출 수율은 에탄올의 농도가 증가함에 따라 감소하였으며 $(10.87-8.07 \%), 70 \% \mathrm{EtOH}, 6 \mathrm{~h}$ 조건에서 추 출 온도가 증가함에 따라 추출 수율은 증가하였다 $\left(60^{\circ} \mathrm{C}\right.$, $\left.14.77 \% ; 80^{\circ} \mathrm{C}, 16.83 \%\right)$. 또한, 추출 시간의 영향을 $70 \%$ $\mathrm{EtOH}, 80^{\circ} \mathrm{C}$ 에서 3-48 h 추출을 비교한 결과, 24 시간까지 추출 수율은 유지되었지만(14.33-16.83\%), 48시간의 경 우 $11.58 \%$ 로 다소 감소되었다.

여러 추출 조건(용매, 온도, 시간)에서의 보리수나무 잎 추출물의 gallic acid와 kaempferol의 함량을 HPLC를 이용 하여 분석한 결과는 Table 1에 나타내었다. 추출 조건에 따른 보리수나무 잎 추출물의 gallic acid와 kaempferol의 함량은 두 성분 모두 에탄올 농도와 온도가 높을수록 증가 하였으며, 6 시간에서 최대치를 나타냈다. $70 \% \mathrm{EtOH}, 80^{\circ} \mathrm{C}$ 의 추출 조건에서 추출 시간을 다양하게 변화하면 추출 시간이 6시간일 때 gallic acid의 함량이 가장 높았다. 즉, $70 \% \mathrm{EtOH}, 80^{\circ} \mathrm{C}, 6 \mathrm{~h}$ 가 gallic acid 및 kaempferol 함량이 가장 높은 추출 조건임을 확인하였다.

본 연구에서는 보리수나무 잎 추출물의 추출 조건을 확 립하기 위하여 추출 용매, 추출 온도, 추출 시간을 다양하게 선정하여 보리수나무 잎의 추출물을 제조하였다. 본 연구 결과에 따르면 추출에 사용한 에탄올의 농도는 $70 \%$ 이며, $80^{\circ} \mathrm{C}$ 의 추출 온도에서 6 시간 동안 추출할 때 가장 높은 추출 수율과 gallic acid 및 kaempferol의 함량을 나타냈다. Gallic acid의 함유량이 높다고 보고된 녹차, 우롱차, 홍차, 푸에르 차에서 각각 $0.74 \mathrm{mg} / \mathrm{g}, 1.42 \mathrm{mg} / \mathrm{g}, 2.06 \mathrm{mg} / \mathrm{g}, 5.53 \mathrm{mg} / \mathrm{g}$ 으로 보리수나무 잎 추출물이 8.2-61.6배 높은 것을 알 수 있다 
Table 1. Extraction yield, and the contents of gallic acid, and kaempferol of $E$. umbellata leaf extract by solvent concentration, temperature and time

\begin{tabular}{cccccc}
\hline & Extraction condition & & Extraction yield $(\%)$ & Gallic acid $(\mu \mathrm{g} / \mathrm{mg})$ & Kaempferol $(\mu \mathrm{g} / \mathrm{mg})$ \\
\cline { 1 - 3 } EtOH $(\%)$ & Temperature $\left({ }^{\circ} \mathrm{C}\right)$ & Time $(\mathrm{h})$ & 10.87 & 18.11 & 0 \\
\hline 0 & 20 & 6 & 10.86 & 20.70 & 0.23 \\
50 & 20 & 6 & 8.61 & 22.49 & 0.21 \\
70 & 20 & 6 & 8.07 & 26.87 & 0.80 \\
70 & 20 & 6 & 14.77 & 29.83 & 0.92 \\
70 & 60 & 6 & 16.83 & 45.60 & 1.16 \\
70 & 80 & 3 & 14.33 & 29.45 & 1.04 \\
70 & 80 & 12 & 14.82 & 37.39 & 1.01 \\
70 & 80 & 24 & 14.35 & 37.56 & 1.10 \\
70 & 80 & 48 & 11.58 & 30.05 & 1.14 \\
\hline
\end{tabular}

(Zuo 등, 2002). 또한, 녹차 내 함유된 kaempferol의 함량은 $0.053 \mathrm{mg} / \mathrm{g}$ 으로 보리수나무 잎 추출물과 비교하면 21.9배의 함량 차이를 보였다(Zhao 등, 2011).

\section{추출 조건에 따른 추출물의 항산화 효과}

정상적인 세포에서는 superoxide dismutase(SOD), catalase, peroxidase 등의 항산화 효소의 작용으로 활성 산소로부터 보호하고 있다. 그러나 방어기구에서의 이상이 초래되면 $\mathrm{ROS}$ 의 발생량이 증가하게 되고, 산화적 스트레스(oxidative stress)를 야기한다. 본 연구에서는 보리수나무 잎의 oxidative stress를 예방할 수 있는 식용 소재로의 가능성을 제시하기 위해 보리수나무 잎 추출물의 항산화 활성을 평가하기 위해 $\mathrm{DPPH}$ 와 $\mathrm{ABTS}$ 라디칼 소거능과 총 폴리페 놀 및 플라보노이드 함량을 측정하였으며, 그 결과는 Table 2에 나타내었다. DPPH radical 소거능에 대한 $\mathrm{IC}_{50}$ 은 추출 용매의 비율이 증가함에 따라 보리수나무 잎 추출물 의 DPPH 라디칼에 대한 소거능이 우수하며, 추출 용매를 포함한 여러 추출 조건에서 $\mathrm{DPPH}$ 의 라디칼 소거능이 가 장 좋은 보리수나무 잎 추출 조건은 $70 \% \mathrm{EtOH}$ 에서 $80^{\circ} \mathrm{C}$, 6시간 동안 추출한 조건으로 $\mathrm{IC}_{50}$ 이 $8.64 \pm 0.31 \mu \mathrm{g} / \mathrm{mL}$ 를 나타내었다. 또한, ABTS 라디칼 소거능에 대한 보리수나 무 잎 추출물의 $\mathrm{IC}_{50}$ 또한 $70 \% \mathrm{EtOH}$ 에서 $80^{\circ} \mathrm{C}, 6$ 시간 동안 추출한 조건에서 $\mathrm{IC}_{50}$ 이 $9.44 \pm 0.48 \mu \mathrm{g} / \mathrm{mL}$ 로 가장 좋은 $\mathrm{ABTS}$ 라디칼 소거능을 보였다. 보리수나무 잎 추출물의 총 폴리페놀 및 플라보노이드 함량은 추출 용매의 비율이 증가함에 따라 증가하였고, $70 \% \mathrm{EtOH}$ 에서 $80^{\circ} \mathrm{C}, 12$ 시간 동안 추출한 조건에서 폴리페놀, 플라보노이드 함량이 각 각 $243.65 \pm 1.96 \mu \mathrm{g} / \mathrm{mg}, 41.44 \pm 0.88 \mu \mathrm{g} / \mathrm{mg}$ 으로 가장 높은
함량을 나타냈다. 보리수나무 잎 추출물의 gallic acid와 kaempferol의 함량과 항산화 활성을 비교하면 보리수나무 잎 추출물의 $\mathrm{DPPH}, \mathrm{ABTS}$ 라디칼 소거능은 $70 \% \mathrm{EtOH}$ 에 서 $80^{\circ} \mathrm{C}, 6$ 시간 동안 추출한 조건에서 가장 좋은 결과를 나타냈다. 반면, 보리수나무 잎 추출물의 폴리페놀 및 플 라보노이드 함량은 $70 \% \mathrm{EtOH}$ 에서 $80^{\circ} \mathrm{C}, 12$ 시간 동안 추 출한 조건에서 가장 높게 나타났다.

항산화 효능과 피부질환 관계에 대한 보고로 제주조릿 대 잎(Lee 등, 2018), 고마리(Gwak과 Kim, 2018), 들깨 새싹 (Jeong 등, 2014)과 국내자생식물 추출물(Kim 등, 2012) 등이 있으며, 폴리페놀과 플라보노이드 함량이 높을수록 항산화 효과가 좋았으며, 특히, 국내자생식물 추출물의 $\mathrm{DPPH}$ 라디칼 소거능에 대한 $\mathrm{IC}_{50}$ 은 대부분 $12.5 \mu \mathrm{g} / \mathrm{mL}$ 이상으로 나타나 보리수나무 잎 추출물과 비교하면 약 1.3 배의 차이를 보여 보리수나무 잎 추출물이 보고된 추출 물에 비교하여 탁월한 항산화 효능을 가짐을 알 수 있다.

\section{추출 조건에 따른 추출물의 항염증 활성}

Nitric oxide(NO)는 대식세포가 LPS로 자극될 때 inducible nitric oxide synthase(iNOS)가 발현되어 세포 외부로 전염 증 인자인 $\mathrm{NO}$ 를 생성하며, $\mathrm{NO}$ 는 과산화질소 등의 활성산 소 결합종에 의해 염증반응을 나타낸다. 따라서 항염증 효능을 확인하는 biomarker로서 대식세포의 NO 생성 억 제능을 측정하는 방법이 일반적이다. 본 연구에서는 보리 수나무 잎 추출물에 대한 RAW264.7 세포의 세포생존율 은 MTT assay로 확인하였다. 에탄올의 농도, 추출 온도, 추출 시간별 보리수나무 잎 추출물에 대한 RAW264.7 macrophage의 세포 생존율은 모든 처리 농도에서 세포 
Table 2. Anti-oxidative activity of $E$. umbellata leaf extract by solvent concentration, temperature and time

\begin{tabular}{|c|c|c|c|c|c|c|}
\hline \multicolumn{3}{|c|}{ Extraction condition } & \multicolumn{2}{|c|}{ Radical scavenging activity $\left(\mathrm{IC}_{50}, \mu \mathrm{g} / \mathrm{mL}\right)$} & \multicolumn{2}{|c|}{ Content $(\mu \mathrm{g} / \mathrm{mg})$} \\
\hline EtOH (\%) & Temperature $\left({ }^{\circ} \mathrm{C}\right)$ & Time (h) & DPPH & ABTS & Polyphenol & Flavonoid \\
\hline 0 & 20 & 6 & $50.11 \pm 13.41^{2) a 3)}$ & $15.38 \pm 0.62^{\mathrm{a}}$ & $152.98 \pm 3.20^{\mathrm{g}}$ & $6.78 \pm 0.70^{\mathrm{g}}$ \\
\hline 20 & 20 & 6 & $41.38 \pm 13.41^{\mathrm{ab}}$ & $12.95 \pm 0.18^{\mathrm{b}}$ & $195.89 \pm 2.38^{\mathrm{f}}$ & $7.83 \pm 0.28^{\mathrm{g}}$ \\
\hline 50 & 20 & 6 & $26.85 \pm 1.64^{\mathrm{bc}}$ & $10.87 \pm 0.06^{\mathrm{c}}$ & $231.31 \pm 2.75^{\mathrm{bc}}$ & $10.30 \pm 0.59^{\mathrm{f}}$ \\
\hline 70 & 20 & 6 & $22.51 \pm 0.66^{\mathrm{bc}}$ & $12.02 \pm 0.25^{\mathrm{b}}$ & $221.51 \pm 4.99^{\mathrm{cd}}$ & $17.10 \pm 0.56^{\mathrm{e}}$ \\
\hline 70 & 60 & 6 & $15.16 \pm 0.94^{\text {cd }}$ & $7.85 \pm 0.21^{\mathrm{e}}$ & $212.60 \pm 1.71^{\mathrm{de}}$ & $31.33 \pm 0.57^{\mathrm{d}}$ \\
\hline 70 & 80 & 6 & $9.54 \pm 0.66^{\mathrm{cd}}$ & $6.69 \pm 0.34^{\mathrm{f}}$ & $241.15 \pm 7.93^{\mathrm{ab}}$ & $37.45 \pm 0.94^{\mathrm{b}}$ \\
\hline 70 & 80 & 3 & $12.26 \pm 0.69^{\mathrm{cd}}$ & $9.96 \pm 0.14^{\text {cd }}$ & $203.43 \pm 3.41^{\mathrm{ef}}$ & $33.47 \pm 0.44^{\mathrm{c}}$ \\
\hline 70 & 80 & 12 & $13.92 \pm 1.26^{\mathrm{cd}}$ & $7.36 \pm 0.71^{\mathrm{ef}}$ & $243.65 \pm 1.96^{\mathrm{a}}$ & $41.44 \pm 0.88^{\mathrm{a}}$ \\
\hline 70 & 80 & 24 & $15.23 \pm 2.50^{\mathrm{cd}}$ & $10.76 \pm 0.22^{\mathrm{c}}$ & $230.83 \pm 1.67^{\mathrm{bc}}$ & $38.82 \pm 0.40^{b}$ \\
\hline 70 & 80 & 48 & $16.96 \pm 7.76^{\mathrm{cd}}$ & $9.12 \pm 0.05^{\mathrm{d}}$ & $222.12 \pm 1.59^{\mathrm{cd}}$ & $38.25 \pm 0.47^{\mathrm{b}}$ \\
\hline \multicolumn{3}{|c|}{ Gallic acid (positive control) } & $2.51 \pm 0.51^{\mathrm{d}}$ & $1.65 \pm 0.16^{\mathrm{g}}$ & $\mathrm{NA}^{1)}$ & NA \\
\hline
\end{tabular}

${ }^{1)} \mathrm{NA}$, not applicable.

${ }^{2}$ Results are expressed as means \pm SD (\% control) of three independent experiments.

${ }^{3)-g}$ Values with different superscript letters are significantly different $(p<0.05)$ by Tukey's multiple comparision test.

독성이 나타나지 않았다(Fig. 1A). 그리고 LPS의 자극에 의해 RAW264.7 macrophage에서 생성되는 NO에 대한 보 리수나무 잎 추출물의 NO 억제 효과를 Griess reagent를 이용하여 측정하였다. LPS 처리 후 $\mathrm{NO}$ 의 생성량은 대조 군에 비교하여 약 15 배 이상 증가되었으며 $(28.85 \mu \mathrm{M})$, 보 리수나무 잎 추출물의 농도별 $(100 \mu \mathrm{g} / \mathrm{mL}, 250 \mu \mathrm{g} / \mathrm{mL}, 500$ $\mu \mathrm{g} / \mathrm{mL}$ )의 $\mathrm{NO}$ 생성능 측정 결과, 모든 처리 농도에서 $\mathrm{NO}$ 생성이 효과적으로 억제되는 것으로 나타났으며, $500 \mu \mathrm{g} / \mathrm{mL}$ 의 동일한 농도에서의 보리수나무 잎 추출물 $\left(70 \%, 80^{\circ} \mathrm{C}, 6 \mathrm{~h}\right)$ 에서 약 $70.4 \%$ 감소된 $8.53 \mu \mathrm{M}$ 의 $\mathrm{NO}$ 생성 으로 다른 추출 조건에서의 보리수나무 잎 추출물과 비교 하면 가장 우수한 $\mathrm{NO}$ 생성 억제 효과를 나타냈다(Fig. 1B). Positive control인 L-NAME에서는 대식 세포주에 대한 세 포 독성이 없었으며, $\mathrm{NO}$ 생성량은 대조군과 비교하면 약 $48.2 \%$ 의 감소를 확인하였다.

피부 질환은 대식세포의 염증 작용과 관계가 있다. 대식 세포의 대식 작용은 외부에서 침투한 박테리아, 바이러스 등을 대식함으로써 과생성되는 부산물에 의해 염증 질환 을 일으키게 된다. 대부분 염증은 조직에 침투한 대식세포 에서 생성되는 ROS가 핵전사인자(nuclear transcription factor $\mathrm{kB}, \mathrm{NFKB}$ )의 경로를 통해 전염증 사이토카인을 암 호화하는 유전자들의 발현을 조절함으로써 염증반응을 매개한다고 알려져 있다. 피부 질환과 항염 활성을 비교한 국내자생식물 추출물 181 종의 보고 사례 중, $100 \mu \mathrm{g} / \mathrm{mL}$ 의 동일한 농도에서의 참가시나무 줄기, 조팝나무 잎, 물오리
나무 수피, 개옻나무 잎, 좀사방 오리나무 줄기 추출물에 서 각각 $99 \pm 1.8,98 \pm 0.9,97 \pm 1.1,95 \pm 1.6,92 \pm 0.7 \%$ 의 산화질 소 억제를 보이며, 181 종 중, 약 120 종의 추출물은 $40 \%$ 미만의 산화질소 억제를 보임으로써 보리수나무 잎 추출 물 $(100 \mu \mathrm{g} / \mathrm{mL}$ 의 농도에서 $33.4 \%$ 의 산화질소 억제)과 비교 하면 최대 2.9 배의 항염 활성의 차이를 나타냈다 $(\mathrm{Kim}$ 등, 2012a). 이는 보리수나무 잎 추출물이 현재까지 보고된 추출물과 비교하면 항염 활성이 우수하지는 않지만, 유효 적인 항염 활성을 가짐을 시사한다.

\section{추출 조건에 따른 추출물의 항균력 비교}

여드름 발생의 주요한 원인은 여드름 유발균인 P. acnes 의 증식으로, 염증 유발과 면역반응을 유도하고, 각질형성 세포를 자극하여 다량의 superoxide anion $\left(\mathrm{O}_{2} \cdot{ }^{-}\right)$을 생성 한다. 이렇게 생성된 $\mathrm{O}_{2}$ - ${ }^{-}$는 $\mathrm{NO}$ 와 함께 peroxynitrites 형태로 각질형성세포의 용해에 관련한다(Bowe와 Shalita, 2008). 또한, P. acnes는 각질형성세포의 분화를 조절하여 피부조직의 염증반응을 유도하는 작용을 하기 때문에 염 증성 여드름 병변의 발생에 중요한 역할을 한다. 그리고 피부조직에서 미세면포(microcomedo)를 형성하여 피지 가 피부 표면으로 방출되는 것을 방해한다(Dessinioti와 Katsambas, 2010). 면포 부위에서 ROS의 과도한 생성은 P. acnes 증식 저해 물질의 억제를 야기하여 피지 내 squalen은 triterpenoid로 지질과산화 과정에서 생성되는 superoxide의 소거능이 있어 피부를 보호하지만, squalen 
(A)

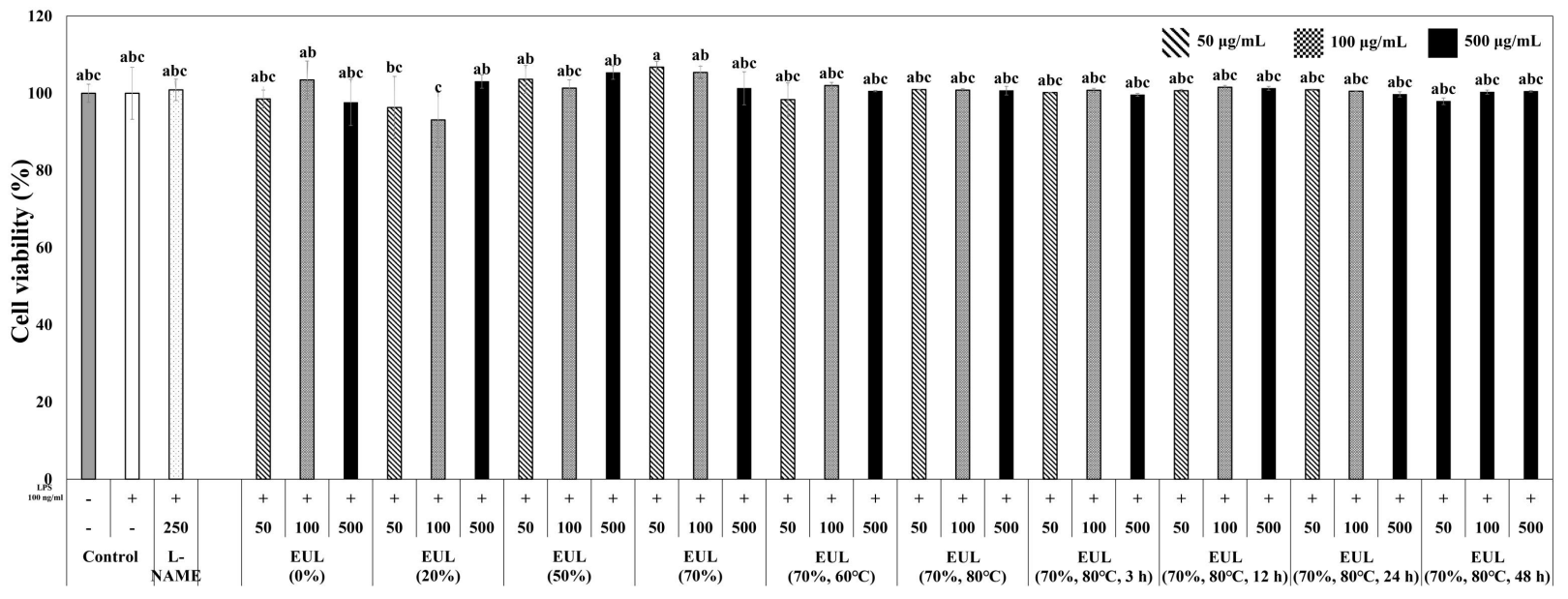

(B)

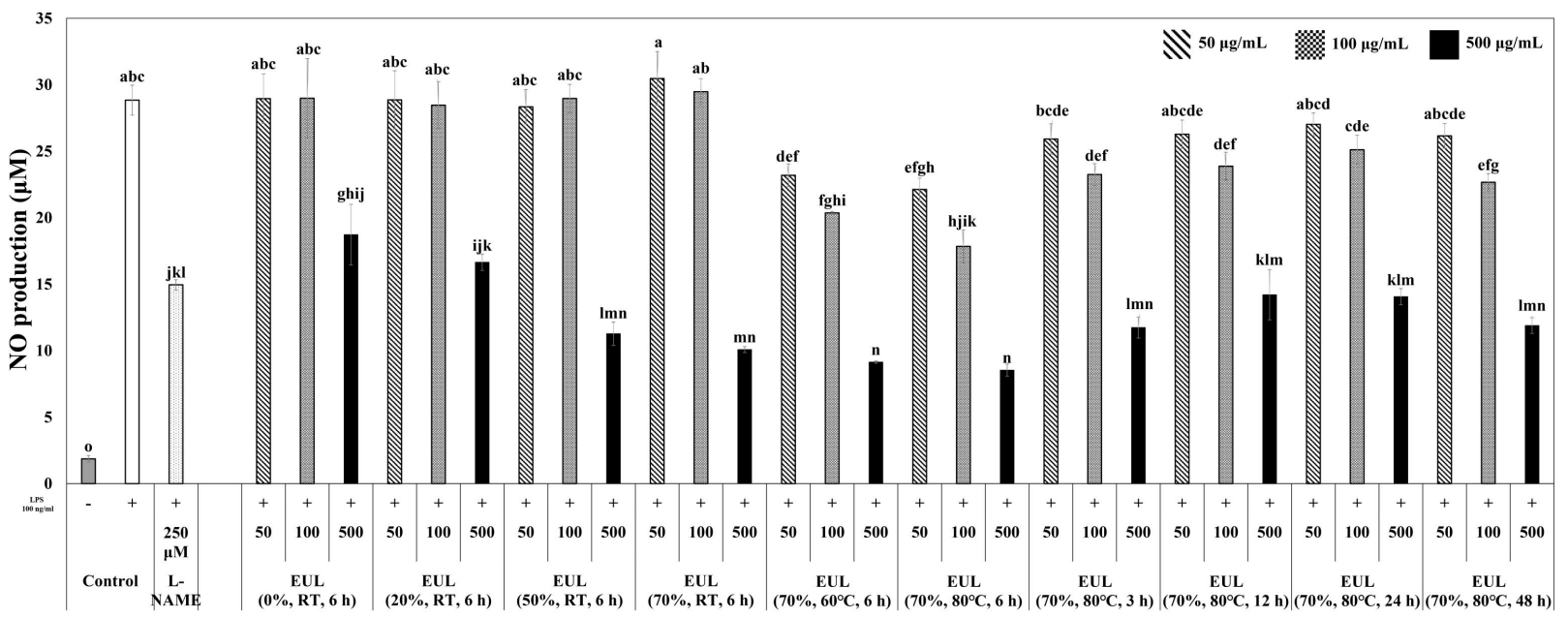

Fig. 1. Anti-inflammatory activity of $E$. umbellata leaf extracts by extraction conditions (solvent concentration, temperature, and time), (A) cell viability of RAW264.7 macrophage by $E$. umbellata leaf extracts, and (B) nitric oxide (NO) production of LPS-stimulated RAW264.7 macrophage by $E$. umbellata leaf extracts.

L-NAME $(250 \mu \mathrm{M})$ was used as a positive control. Results are expressed as means \pm SD (\% control) of three independent experiments. Values with different superscript letters are significantly different $(\mathrm{p}<0.05)$ by Tukey’s multiple comparision test.

peroxide가 생성되면 면포 형성과 inflammatory mediator를 생성하고, 세균의 집락화를 유도한다(Akamatsu 등, 2003; Ottaviani 등, 2006). 따라서 본 연구에서는 E. coli, S. aureus, P. acnes 균주에 대한 보리수나무 잎 추출물의 항 균 활성은 disc diffusion method를 수행하여 생육저해환의 크기를 비교, 분석하였다.

보리수나무 잎 추출물의 P. acnes와 E. coli에 대한 항균 활성은 Table 3 에 나타낸 것과 같이 $70 \% \mathrm{EtOH}$ 과 6시간의 추출 시간을 고정하고 추출 온도에서의 변화에 따른 항균 활성이 추출 용매, 추출 시간을 변화한 추출물에 비해 우 수한 것을 알 수 있었다. P. acnes와 E. coli에 대한 chloram- phenicol(positive control $0.1 \mathrm{mg} / \mathrm{mL}$ )의 생육저해환은 각각 $5.0 \pm 0.5 \mathrm{~mm}$ 및 $10.0 \pm 0.6 \mathrm{~mm}$ 로 나타났다. 한편, 보리수나무 잎 추출물의 $S$. aureus에 대한 항균 활성은 $50 \% \mathrm{EtOH}$ 와 $20^{\circ} \mathrm{C}$ 의 온도에서 6 시간 동안 추출한 추출물에서 $6.5 \pm 0.5$ $\mathrm{mm}$ 로 가장 우수한 생육저해환이 나타나, 추출 용매의 농 도가 $50-70 \%$, 추출 온도가 $20-800^{\circ} \mathrm{C}$ 로 6 시간 동안 추출 한 추출물에서 가장 좋은 항균 활성을 나타내었다. Chloramphenicol의 생육저해환은 약 $5.2 \pm 0.4 \mathrm{~mm}$ 로 나타났다.

따라서, 보리수나무 잎의 최적 추출은 P. acnes에 대한 항균 활성을 기준하면 $70 \%$ 의 에탄올 농도에서 $80^{\circ} \mathrm{C}$ 의 추출 온도로 6 시간 동안 추출한 추출물에서 가장 우수한 
Table 3. Anti-microbial activity of $E$. umbellata leaf extract for $P$. acnes, $S$. aureus, and $E$. coli by solvent concentration, temperature and time

\begin{tabular}{|c|c|c|c|c|c|}
\hline \multicolumn{3}{|c|}{ Extraction condition } & \multicolumn{3}{|c|}{ Clear zone (mm) } \\
\hline $\mathrm{EtOH}(\%)$ & Temperature $\left({ }^{\circ} \mathrm{C}\right)$ & Time (h) & P. acnes & S. aureus & E. coli \\
\hline 0 & 20 & 6 & $0.0 \pm 0.0^{2) \mathrm{d} 3)}$ & $5.0 \pm 0.0^{\mathrm{bc}}$ & $5.5 \pm 0.5^{\mathrm{c}}$ \\
\hline 20 & 20 & 6 & $0.0 \pm 0.0^{\mathrm{d}}$ & $5.5 \pm 0.5^{\mathrm{bc}}$ & $8.0 \pm 0.0^{\mathrm{ab}}$ \\
\hline 50 & 20 & 6 & $4.2 \pm 0.8^{\mathrm{c}}$ & $6.5 \pm 0.5^{\mathrm{a}}$ & $8.8 \pm 0.8^{\mathrm{a}}$ \\
\hline 70 & 20 & 6 & $6.2 \pm 0.6^{\mathrm{ab}}$ & $6.0 \pm 0.0^{\mathrm{ab}}$ & $9.0 \pm 1.0^{\mathrm{a}}$ \\
\hline 70 & 60 & 6 & $6.7 \pm 0.6^{\mathrm{ab}}$ & $6.0 \pm 0.0^{\mathrm{ab}}$ & $8.0 \pm 0.0^{\mathrm{ab}}$ \\
\hline 70 & 80 & 6 & $7.0 \pm 0.4^{\mathrm{a}}$ & $6.3 \pm 0.5^{\mathrm{ab}}$ & $8.8 \pm 0.3^{\mathrm{a}}$ \\
\hline 70 & 80 & 3 & $5.3 \pm 1.0^{\mathrm{bc}}$ & $5.3 \pm 0.2^{\mathrm{bc}}$ & $6.5 \pm 0.5^{\mathrm{bc}}$ \\
\hline 70 & 80 & 12 & $5.7 \pm 0.9^{\mathrm{bc}}$ & $5.5 \pm 1.0^{\mathrm{bc}}$ & $5.8 \pm 0.8^{\mathrm{bc}}$ \\
\hline 70 & 80 & 24 & $5.3 \pm 0.5^{\mathrm{bc}}$ & $5.5 \pm 0.5^{b c}$ & $6.0 \pm 1.0^{\mathrm{bc}}$ \\
\hline 70 & 80 & 48 & $6.0 \pm 0.8^{\mathrm{bc}}$ & $4.5 \pm 0.5^{\mathrm{c}}$ & $4.5 \pm 1.5^{\mathrm{c}}$ \\
\hline \multicolumn{3}{|c|}{ Chloramphenicol $^{1)}$} & $5.0 \pm 0.5^{\mathrm{bc}}$ & $5.2 \pm 0.4^{\mathrm{bc}}$ & $10.0 \pm 0.6^{\mathrm{a}}$ \\
\hline
\end{tabular}

${ }^{1)}$ Chloramphenicol was used as a positive control.

${ }^{2}$ Results are expressed as means \pm SD (\% control) of three independent experiments.

${ }^{3) a-d}$ Values with different superscript letters are significantly different $(\mathrm{p}<0.05)$ by Tukey's multiple comparision test.

항균 활성을 나타낼 것으로 사료된다. 현재까지 보고된 논문에 따르면 $S$. aureus의 경우, 고농도(1,500 $\mu \mathrm{g} / \mathrm{disc})$ 의 갓 에탄올 추출물(Kang 등, 1994)에서의 항균 활성을 나 타내는 생육저해환의 크기는 $14 \mathrm{~mm}$ 이며, 연잎 에탄올 추출물(Lee 등, 2012)에서는 고농도(1,000 $\mu \mathrm{g} / \mathrm{disc})$ 조건에 서 P. acnes와 S. aureus의 생육저해환의 크기가 각각 $10.69 \mathrm{~mm}, 8.97 \mathrm{~mm}$ 로 나타나며, 보골지, 당후박, 솔잎, 오미자 등의 추출물에서 P. acnes와 S. aureus의 항균 및 우수한 항염 활성을 나타낸다는 보고가 있다 $(\mathrm{Ku}$ 와 Park, 2018). 따라서 본 연구에서 사용한 보리수나무 잎 추출물 은 저농도(100 $\mu \mathrm{g} / \mathrm{disc})$ 에서 항균 활성이 $6.3 \mathrm{~mm}$ 로 나타나 보고된 추출물들과 비교하면 우수한 항균 활성을 가짐을 알 수 있었다.

이는 보리수나무 잎 추출물이 피부 염증을 효과적으로 제어하고, 피부에 존재하는 피부 상재균의 사멸을 유도함 을 의미한다. 향후 보리수나무 잎 추출물은 항균 및 항염 증 보호를 통해 피부 관련제품에 탁월한 기능성 소재가 될 수 있을 것으로 사료된다.

\section{요 약}

보리수나무 잎의 최적 추출 조건을 조사하기 위해, 상이 한 추출 조건 하에서 제조된 추출물의 항산화, 항염증 및 항균 효과를 평가하였다. 주요 성분으로 알려진 gallic acid 및 kaempferol을 HPLC로 정량 분석 하였다. 보리수나무
잎 추출물은 항산화 활성에 대하여 $\mathrm{DPPH}$ 및 $\mathrm{ABTS}$ 라디칼 소거능, 폴리페놀 및 플라보노이드의 함량을 측정하였으 며, 항염증 효과를 위하여 LPS로 자극된 RAW264.7 세포 에서의 산화질소 생성 억제, Propionibacterium acnes, Staphylococcus aureus, Escherichia coli에 대한 항균 활성 은 disk diffusion 분석에 의해 조사되었다. 여러 추출물 중에서 $80^{\circ} \mathrm{C}$ 에서 6 시간 동안 $70 \% \mathrm{EtOH}$ 를 사용한 추출물 은 라디칼 소거 $\left(\mathrm{IC}_{50} ; \mathrm{DPPH}\right.$ 에 대해 $8.64 \pm 0.31 \mu \mathrm{g} / \mathrm{mL}$, ABTS에 대해 $9.44 \pm 0.48 \mu \mathrm{g} / \mathrm{mL}), \mathrm{RAW} 264.7$ 세포에서 산 화질소 억제 $(500 \mu \mathrm{g} / \mathrm{mL}$ 에서 $39.6 \%)$ 에 대하여 최상의 활성 을 나타냈다. 또한, $50-70 \% \mathrm{EtOH}$ 와 $20-80^{\circ} \mathrm{C}$ 의 추출 온 도에서 6시간 동안 추출한 추출물에서 우수한 항균 활성 (P. acnes, S. aureus, E. coli에 대하여 7.0 $\pm 0.4,6.5 \pm 0.5$ 및 $9.0 \pm 1.0 \mathrm{~mm})$ 을 나타내었다. 또한, 추출물은 gallic acid (45.60 $\mu \mathrm{g} / \mathrm{mg}), \mathrm{kaempferol}(1.16 \mu \mathrm{g} / \mathrm{mg})$ 및 추출 수율(16.83 $\%$ )의 함량이 가장 높았다. 따라서 우리의 데이터는 gallic $\mathrm{acid}$ 가 풍부한 보리수나무 잎 추출물이 항산화, 항염증 및 항균 효과를 나타내며, 피부 노화 및/또는 여드름 및 아토피와 같은 문제로부터 보호하기 위한 우수한 식품 재료로 사용될 수 있음을 시사한다.

\section{감사의 글}

이 논문은 정부(교육부)의 재원으로 한국연구재단-대학 혁신지원사업의 지원을 받아 수행된 연구임. 


\section{Conflict of interests}

The authors declare no potential conflict of interest.

\section{ORCID}

Ha-Rin Kang https://orcid.org/0000-0002-1422-4465

Seun-Ah Yang https://orcid.org/0000-0002-6692-1844

\section{References}

Abri A, Maleki M. Isolation and identification of gallic acid from the Elaeagnus angustifolia leaves and determination of total phenolic, flavonoids contents and investigation of antioxidant activity. J Iran Chem Commun, 4, 133-235 (2016)

Akamatsu H, Horio T, Hattori K. Increased hydrogen peroxide generation by neutrophils from patients with acne inflammation. Int J Dermatol, 42, 366-369 (2003)

Bojar RA, Holland KT, Cunliffe WJ. The in-vitro antimicrobial effects of azelaic acid upon Propionibacterium acnes strain P37. J Antimicrob Chemother, 28, 843-853 (1991)

Bowe WP, Shalita AR. Effective over the counter acne treatments. Semin Cutaneous Med Surg, 27, 170-176 (2008)

Chen CH, Hwang TL, Chen LC, Chang TH, Wei CS, Chen JJ. Isoflavones and anti-inflammatory constituents from the fruits of Psoralea corylifolia. Phytochem, 143, 186-193 (2017)

Dessinioti C, Katsambas AD. The role of Propionibacterium acnes in acne pathogenesis: Facts and controversies. Clin Dermatol, 28, 2-7 (2010)

Devi KP, Malar DS, Nabavi SF, Sureda A, Xiao J, Nabavi SM, Daglia M. Kaempferol and inflammation: From chemistry to medicine. Pharmacol Res, 99, 1-10 (2015)

Fernandes FHA, Batista RSA, Medeiros FD, Santos FS, Medeiros ACD. Development of a rapid and simple HPLC-UV method for determination of gallic acid in Schinopsis brasiliensis. Rev Bras Farmacogn, 25, 208-211 (2015)

George M, Joseph L. Anti-allergic, anti-pruritic, and antiinflammatory activities of Centella asiatica extracts. Afr J Trand CAM, 6, 554-559 (2009)

Gwak JS, Kim CD. Anti-oxidant, anti-microbial, anti-inflammatory and anti-allergy effect of Persicaria thunbergii extracts. J Kor Soc Cosmet, 24, 986-992 (2018)

Han SM, Lee KG, Yeo JH, Kim WT, Park KK. Antimicrobial property of honeybee (Apis mellifera $\mathrm{L}$.) venom against Propionibacterium acnes and aerobic skin flora. Kor J Pharmacogn, 40, 173-177 (2009)

Inoue M, Suzuki R, Koide T, Sakaguchi N, Ogihara Y, Yabu Y. Antioxidant, gallic acid, induces apoptosis in HL-60RG cells. Biochem Biophys Res Commun, 204, 898-904 (1994)

Jeong SI, Kim HS, Jeon IH, Kang HJ, Mok JY, Cheon CJ, $\mathrm{Yu} \mathrm{HH}$, Jang SI. Antioxidant and anti-inflammatory effects of ethanol extracts from Perilla frutescens. Korean J Food Sci Technol, 46, 87-93 (2014)

Kang MS, Oh JS, Kang IC, Hong SJ, Choi CH. Inhibitory effect of methyl gallate and gallic acid on oral bacteria. J Microbiol, 46, 744-750 (2008)

Kang SK, Sung NK, Kim YD, Shin SC, Seo JS, Choi KS, Park SK. Screening of antimicrobial activity of leaf mustard (Brassica juncea) extract. J Korean Soc Food Sci Nutr, 23, 1008-1013 (1994)

Kim HH, Kwon JH, Park KH, Kim MH, Oh MH, Choe KI, Park SH, Jin HY, Kim SS, Lee MW. Screening of antioxidative activities and antiinflammatory activities in local native plants. Korean J Pharmacogn, 43, 85-93 (2012a)

Kim HJ, Lim HW, Kim BH, Kim HS, Choi SW, Yoon CS. Studies on the anti-acne effect of Agrimonia pilosa ledeb. J Soc Cosmet Scientist Korea, 32, 53-58 (2006a)

Kim MJ, Lim JS, Yang SA. Component analysis and antiproliferative effects of ethanol extracts of fruits, leaves, and stems from Elaeagnus umbellata in HepG2 cells. J Kor Soc Food Sci Nutr, 45, 828-834 (2016)

Kim NR, Lim YH, Park SW, Nam ES. Antimicrobial activities of the anti-acne compounds from natural sources. Microbiol Biotechnol Lett, 37, 80-84 (2009)

Kim SY, Lee MH, Jo NR, Park SN. Antibacterial activity and skin moisturizing effect of Cedrela sinensis A. Juss shoots extracts. J Soc Cosmet Scientist Korea, 36, 315-321 (2010)

Kim SH, Jun CD, Suk K, Choi BJ, Lim H, Park S, Lee SH, Shin HY, Kim DK, Shin TY. Gallic acid inhibits histamine release and pro-inflammatory cytokine production in mast cells. Toxicol Sci, 91, 123-131 (2006b)

Kim Y, Han J, Sung J, Sung M, Choi Y, Jeong HS, Lee J. Anti-inflammatory activity of Chrysanthemum zawadskii var. latilobum leaf extract through haem oxygenease-1 
induction. J Funct Foods, 4, 474-479 (2012b)

Kobayashi M, Kabashima K, Nakamura M, Tokura Y. Effects of oral antibiotic roxithromycin on quality of life in acne patients. J Dermatol, 36, 383-391 (2009)

Kroes $\mathrm{BH}$, van den Berg AJJ, van Ufford HCQ, van Dijk H, Labadie RP. Anti-inflammatory activity of gallic acid. Planta Med, 58, 499-504 (1992)

$\mathrm{Ku}$ JE, Park CH. Research trends in effective medicinal plants for acne. Korean Soc Cosmet Cosmetol, 8, 431-445 (2018)

Lee CH, Bae JY, Park JH. Pharmacognostical studies on the Korean folk medicine 'BoRiSuNaMu'. Kor J Pharmacogn, 42, 1-5 (2011)

Lee EJ, Seo YM, Kim YH, Chung CW, Sung HJ, Sohn HY, Park JY, Kim JS. Anti-inflammatory activities of ethanol extracts from leaf, seed, and seedpod of Nelumbo nucifera. J Life Sci, 29, 436-441 (2019)

Lee JY, Song H, Ko HC, Jang MG, Kim SJ. Anti-oxidant and anti-inflammatory potentials of Sasa quelpaertensis leaf residue extract. J Life Sci, 28, $738-744$ (2018)

Lee NH, Choi EH, Ahn SK, Lee SH. A clinical study on the effect of a facial cleanser consisting of $1 \%$ triclosan and $0.5 \% \mathrm{Ku}$ Shen on acne vulgaris. Korean J Dermatol, 36, 871-876 (1998)

Lee SS, Imm JY, Han YS. The improvement effect of lotus leaf extracts on acne skin. Asian J Beauty Cosmetol, 10, 405-413 (2012)

Leem MH, Jung EH. Changes of $\mathrm{pH}$, sebum, moisture excreation level of skin surface after benzoyl peroxide lotion treatment on acne skin. Kor J Aesthet Cosmetol, 3, 37-48 (2005)

Leyden JJ, Kaidbey K, Gans EH. The antimicrobial effects in vivo of minocycline, doxycycline and tetracycline in humans. J Dermatol Treat, 7, 223-225 (1996)

Lim YH, Kim IH, Seo JJ. In vitro activity of kaempferol isolated from the impatiens balsamina alone and in combination with erythromycin or clindamycin against Propionibacterium acnes. J Microbiol, 45, 473-477 (2007)

Oh JH, Kang LL, Ban JO, Kim YH, Kim KH, Han SB, Hong JT. Anti-inflammatory effect of 4-O-methylhonokiol, a novel compound isolated from Magnolia officinalis through inhibition of NF-кB. Chem Biol Interact, 180, 506-514 (2009)

Ohno Y, Fukuda K, Takemura G, Toyota M, Watanabe M, Yasuda N, Xinbin Q, Maruyama R, Akao S, Gotou K,
Fujiwara T, Fujiwara H. Induction of apoptosis by gallic acid in lung cancer cells. Anti-Cancer Drugs, 10, 845-851 (1999)

Ottaviani M, Alestas T, Flori E, Mastrofrancesco A, Zouboulis CC, Picardo M. Peroxidated squalene induces the production of inflammatory mediators in HaCaT keratinocytes: A possible role in acne vulgaris. J Invest Dermatol, 126, 2430-2437 (2006)

Park J, Lee J, Jung E, Park Y, Kim K, Park B, Jung K, Park E, Kim J, Park D. In vitro antibacterial and anti-inflammatory effects of honokiol and magnolol against Propionibacterium sp.. Eur J Pharmacol, 496, 189-195 (2004)

Park SH, Jhee KH, Yang SA. Protective effects of an ethanol extract of Elaeagnus umbellata leaves on $\alpha$-MSH-induced melanin production in B16-F0 cells and UVB-induced damage in CCD-986sk cells. J Life Sci, 29, 555-563 (2019)

Pechere M, Germanier L, Siegenthaler G, Pechere JC, Saurat JH. The antibacterial activity of topical retinoids: The case of retinaldehyde. Dermatol, 205, 153-158 (2002)

Rafique N, Khan T, Shah AJ. Calcium entry blocking activity of the Elaeagnus umbellata fruit extract explains its use in diarrhea and gut spasm. Bangladesh J Pharmacol, 11, 585-592 (2016)

Sharma V, Joseph C, Ghosh S, Agarwal A, Mishra MK, Sen E. Kaempferol induces apoptosis in glioblastoma cells through oxidative stress. Mol Cancer Ther, 6, 2544-2553 (2007)

Shen X, Guo M, Yu H, Liu D, Lu Z, Lu Y. Propionibacterium acnes related anti-inflammation and skin hydration activities of madecassoside, a pentacyclic triterpene saponin from Centella asiatica. Biosci Biotechnol Biochem, 83, 561-568 (2018)

Sohn HY, Kim YS, Kum EJ, Kwon YS, Son KH. Screening of anti-acne activity of natural products against Propionibacterium acnes. Microbiol Biotechnol Lett, 34, 265-272 (2006)

Wang FM, Yao TW, Zeng S. Determination of quercetin and kaempferol in human urine after orally administrated tablet of Ginkgo biloba extract by HPLC. J Pharm Biomed Anal, 33, 317-321 (2003)

Wang H, Helliwell K, You X. Isocratic elution system for the determination of catechins, caffeine and gallic acid in green tea using HPLC. Food Chem, 68, 115-121 (2000) Wang Q, Gao S, Wu G, Yang N, Zu X, Li W, Xie N, Zhang 
R, Li C, Hu Z, Zhang W. Total sesquiterpene lactones isolated from Inula helenium L. attenuates 2,4-dinitrochlorobenzene-induced atopic dermatitis-like skin lesions in mice. Phytomedicine, 46, 78-84 (2018)

Weon JB, Ahn JH, Ma CJ. Antibacterial activity of some medicinal plants against Propionibacterium acnes. Kor J Pharmacogn, 42, 98-101 (2011)

Yen GC, Duh PD, Tsai HL. Antioxidant and pro-oxidant properties of ascorbic acid and gallic acid. Food Chem, 79, 307-313 (2002)

Yoon KY, Hong JY, Shin SR. Analysis on the components of the Elaeagnus multiflora Thunb. Korean J Food Preserv, 14, 639-644 (2007)

Zhao Y, Chen P, Lin L, Harnly JM, Yu L, Li Z. Tentative identification, quantitation, and principal component analysis of green pu-erh, green, and white teas using UPLC/DAD/MS. Food Chem, 126, 1269-1277 (2011)

Zuo Y, Chen H, Deng Y. Simultaneous determination of catechins, caffeine and gallic acids in green, oolong, black and pu-erh teas using HPLC with a photodiode array detector. Talanta, 57, 307-316 (2002) 